\title{
Potential Groundwater Pollution Risks by Heavy Metals from Agricultural Soil in Songon Area (Abidjan, Côte d'Ivoire)
}

\author{
Innocent K. Kouamé ${ }^{1,2^{*}}$, Lazare K. Kouassi ${ }^{3}$, Brou Dibi ${ }^{3}$, Kouamé M. Adou ${ }^{1}$, Ioan D. Rascanu ${ }^{4}$, \\ Gheorghe Romanescu ${ }^{2}$, Issiaka Savané ${ }^{1}$, Ion Sandu ${ }^{2}$
}

${ }^{1}$ Laboratoire de Géosciences et Environnement, Université Nangui Abrogoua, Abidjan, Côte d'Ivoire; ${ }^{2}$ Alexandru Ioan Cuza University, ARHEOINVEST Interdisciplinary Platform, Scientific Research and Conservation of Cultural Heritage Laboratory, Iasi, Romania; ${ }^{3}$ Université Jean Lorougnon Guédé, Daloa, Côte d'Ivoire; ${ }^{4}$ Romanian Waters, National Administration Prut-Barlad Water Branch, Iasi, Romania.

Email: *innocent_kouassi@yahoo.fr

Received August 28 $8^{\text {th }}, 2013$; revised September 27 $7^{\text {th }}, 2013$; accepted October $25^{\text {th }}, 2013$

Copyright (C) 2013 Innocent K. Kouamé et al. This is an open access article distributed under the Creative Commons Attribution License, which permits unrestricted use, distribution, and reproduction in any medium, provided the original work is properly cited. In accordance of the Creative Commons Attribution License all Copyrights (C) 2013 are reserved for SCIRP and the owner of the intellectual property Innocent K. Kouamé et al. All Copyright (C) 2013 are guarded by law and by SCIRP as a guardian.

\begin{abstract}
The soil samples were collected taking into account the land use in Songon area. The hydraulic conductivity (K) of soils was characterized in-situ when specific yield (Sy), pHw and concentrations of Cooper, Iron, Zinc, Cadmium, Chromium and Lead were measured in the laboratory. Pollution load indices (PLI) were calculated to evaluate the soil contamination levels. The soils were neutral and alkaline $(6.7 \leq \mathrm{pH} \leq 9.20)$, permeable $\left(1.9 \times 10^{-5} \mathrm{~m} \cdot \mathrm{s}^{-1} \leq \mathrm{K} \leq 8.2 \times 10^{-4}\right.$ $\left.\mathrm{m} \cdot \mathrm{s}^{-1}\right)$, with a high specific yield $(13.33 \% \leq \mathrm{Sy} \leq 33.33 \%)$ which can favor the pollutants transfer. The heavy metals $(\mathrm{Fe}$, $\mathrm{Cu}, \mathrm{Zn}, \mathrm{Cd}, \mathrm{Cr}$ and $\mathrm{Pb}$ ) have very high concentrations in soils. The integrated pollution indices (PLI) indicate that almost $70 \%$ of Songon soils are moderately contaminated by the investigated heavy metals, with windows presenting high indices of pollution related to the intensive use of fertilizers and pesticides. The establishment of new boreholes in the Songon area should consider these heavy metals, so as to avoid the risk of groundwater pollution due to the physical properties of soils.
\end{abstract}

Keywords: Songon; Soil; Heavy Metals; Pollution Indices; Groundwater Pollution Risk; Abidjan

\section{Introduction}

In areas of intensive agricultural activity, the pollution of groundwater is a consequence of farming practices using large quantities of fertilizers and pesticides [1,2]. The impact of these practices on the groundwater pollution was demonstrated all over the world $[3,4]$. These studies reported that excessive fertilization increases nitrate, phosphorus, potassium and also heavy metals concentrations in groundwater.

Because they generally contribute low concentrations in groundwater pollution, heavy metals from agricultural soils have traditionally been neglected when conducting risk assessment [3]. However, environmental problems due to long-term accumulation of heavy metals in agri-

"Corresponding author. cultural regions have increased in recent years [5,6]. Groundwater pollution by heavy metals mostly comes from agricultural activities like sewage sludge or fertilizer spreading [7], particularly for cadmium (Cd), copper $(\mathrm{Cu})$ and zinc $(\mathrm{Zn})$ [8]. Some other studies indicate higher concentrations in agricultural soils than in "natural" soils $[7,9,10]$, depending on the nature and the duration of the agricultural practices. Increased metal concentrations in the soil pose a serious and current concern for governmental and regulatory bodies for environmental and human risk assessment [11]. Metals present a risk for human health because they are non-degradable pollutants, having a large spectrum of effects (e.g., nervous or digestive system disturbances and carcinogenic effects), especially for young children who are more sensitive than adults [12]. 
Once groundwater is contaminated by heavy metals, it is difficult to remediate, thus the prevention of contamination is the primary strategy to protect groundwater resources [13]. So, to prevent groundwater contamination and preserve population health, studies are often performed on pollution sources, in particular on agricultural soils to know their contamination level by heavy metals that can be transferred into groundwater.

Abidjan is the economic capital of Côte d'Ivoire. Since the 1970 s, more than 90 wells grouped in 10 well fields have been made by the government to satisfy the water needs of the city with about 1 million inhabitants. With an annual growth rate of $3.9 \%$, Abidjan city has now more than 5 million inhabitants and the quantity of produced water has become insufficient to satisfy the water needs estimated at more than 132 million $\mathrm{m}^{3}$. In addition, nitrate and chlorides pollution led to the abandonment in 2001 of a well field of 8 wells thus reducing the ability of managers to provide water to the population. This situation now gives rise to repeatedly water shortages in the city and its surroundings.

To find a solution to this problem, the water resource managers of Côte d'Ivoire, plan to create a groundwater field of 10 boreholes in the Songon area, which located on the western peri-urban zone of Abidjan city. This decision raises suspicions about the quality of water that will be served to the population. Indeed, for over 30 years, large agricultural plantations of rubber, banana and palm trees were created in the Songon area. To improve plant protection and production, pesticides and fertilizers were used in different plantations. Until now, no study has been conducted in this area for assessing the environmental losses of fertilizers and pesticides in soil and groundwater. But [14] used DRASTIC-LU method and showed that $84 \%$ of the Songon area presented a high vulnerability to pollution because the groundwater was at shallow depths often less than $15 \mathrm{~m}$. Thus, the knowledge of the agricultural activities impact on the quality of soil and groundwater should be a good indicator for sustainable implantation of well field in the Songon area.

The present study aims to 1) determine the hydraulic properties of Songon soils that favor pollutants migration, 2 ) assess the level of soil contamination by heavy metals, and 3) determine the indices of pollution distribution in Songon soil.

\section{Materials and Methods}

\subsection{Study Area}

The study area is the Songon city (Figure 1), in the western part of the Abidjan city, between 356,000 and $374,000 \mathrm{~m}$ Eastern longitude and between 584,000 and $599,000 \mathrm{~m}$ Northern latitude of the UTM referential Zone 30 . It covers an area of approximately $120 \mathrm{~km}^{2}$ and is bordered to the south by the Ebrie lagoon. The geology of the area is usually the coastal sedimentary basin in Abidjan. The predominant lithology is the sedimentary formations made from top to bottom of clayey sands, average sands and coarse sands resting on a granitic and schistous base [15]. The climate is humid subtropical with two rainy seasons (April-July and October-November) and two dry seasons (August-September and December-March). The rains are consistent during rainy seasons (150 - $450 \mathrm{~mm}$ per month) and low during the dry seasons (32 - $100 \mathrm{~mm}$ per month). Temperatures range generally between $22^{\circ} \mathrm{C}$ and $29^{\circ} \mathrm{C}$.

\subsection{Soil Sampling}

The soil sampling sites were positioned taking into account the land use in the study area. Geographical coordinates were taken at each sampling site using a GPS Garmin E-Trex. Samples were preferentially carried out in the plantations of rubber, banana, casava and palm trees, and also in some animal farms and in some villages where there is no planting.

The soil samples were taken with an auger to a depth of $40 \mathrm{~cm}$ representing the topsoil. The samples were preserved in labeled bags. Finally, a total of 22 soil samples were collected for analysis during April-May 2010 (Table 1).

\subsection{Soil Physical Properties Characterization}

\subsubsection{Specific Yield}

The specific yield (Sy) reflects the degree of voids interconnection in the aquifer and in which the water is released by gravity. It is expressed by Equation (1) [16]:

$$
S_{y}=\frac{V_{d}}{V_{t}}
$$

where $V_{d}$ is the volume of gravity water that a soil can hold in the saturated state and then released as a result of a complete drainage to its total volume $\left(V_{t}\right)$.

In the study area, the soil samples were weighed into gauged plastic containers. Volumes of water were added into containers until the soil was saturated. After 48 hours of draining, the water volumes collected at the samples were determined. These volumes were used to calculate specific yields.

\subsubsection{Hydraulic Conductivity}

In-situ, the method of double rings infiltrability [17] was used to investigate the spatial distribution of soil hydraulic conductivity in the study area. This method is based on the determination of vertical velocity of water flow through the soil from the Darcy's law. The device used in this study consisted of a central metallic cylinder of about $25 \mathrm{~cm}$ which is pressed $10 \mathrm{~cm}$ into the ground on 


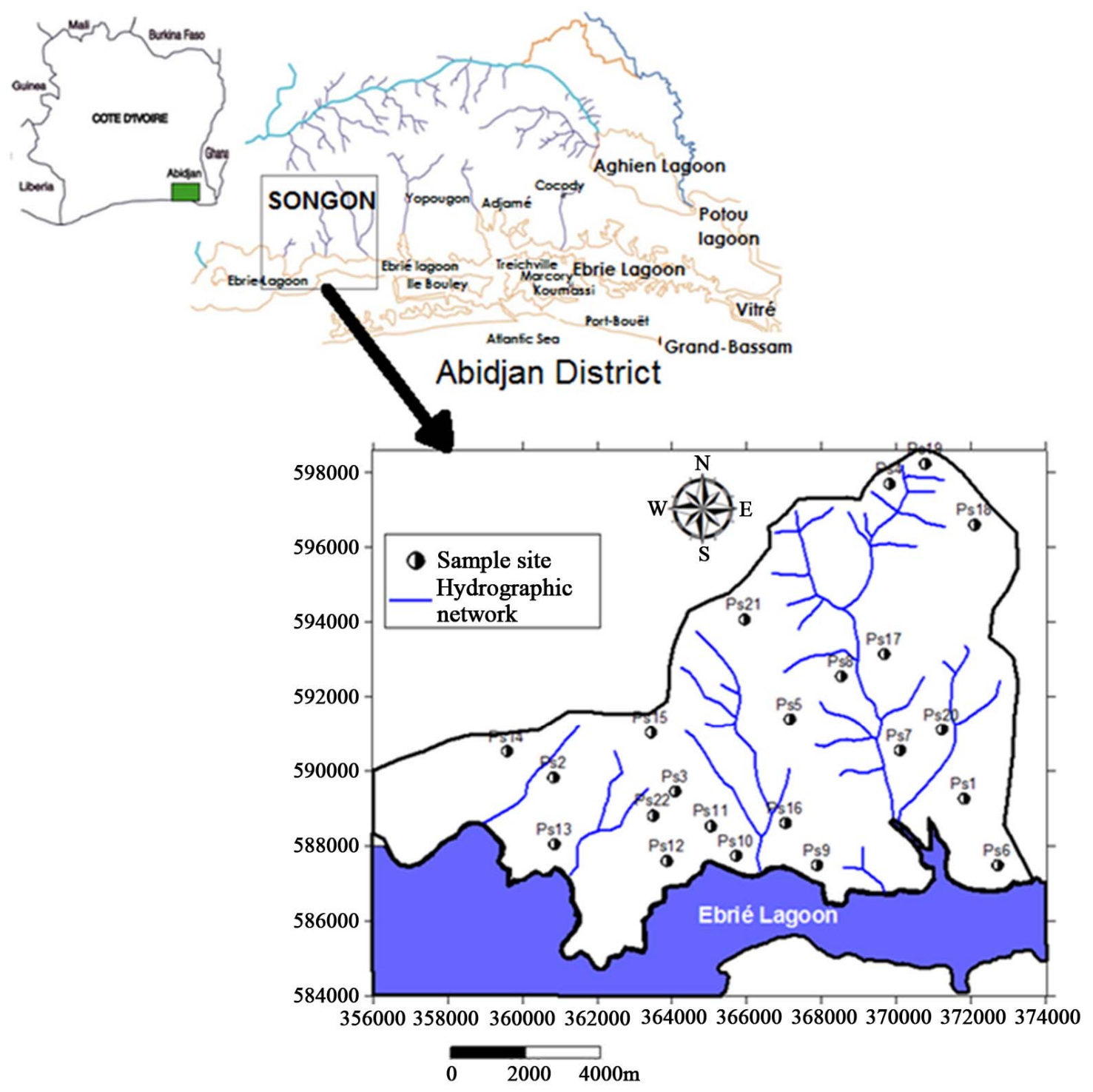

Figure 1. Songon area and sampling sites.

which a Mariotte vase was placed. This vase maintains the water level constant at a certain height above the ground surface. After stabilization of the flow, the volume $V\left(\mathrm{~m}^{3}\right)$ of water infiltrated for a time $T(\mathrm{~s})$ is measured. The infiltration flow $q\left(\mathrm{~m}^{3} / \mathrm{s}\right)$ is evaluated by Equation (2):

$$
q=\frac{V}{T}
$$

Darcy's law is applied according to the infiltration surface $S\left(\mathrm{~m}^{2}\right)$ equal to the section of cylinder and the hydraulic gradient by Equation (3):

$$
K=\frac{V}{S T}
$$

The value of the vertical gradient is equal to 1 and $K$ is expressed in $\mathrm{m} \cdot \mathrm{s}^{-1}$.

\subsection{Soil Samples Analysis}

Soil $\mathrm{pH}\left(\mathrm{pH}-\mathrm{H}_{2} \mathrm{O}\right)$ was measured from deionized water with a $1: 5 \mathrm{soil} /$ solution ratio after equilibration according to French standard NF X31-103. Soil samples were then dried at $105^{\circ} \mathrm{C}$ for 4 hours, crashed and sieved to 0.63 $\mu \mathrm{m}$, according to French standard NF X31-101 and stored in closed plastic bags until analysis. Heavy metals were extracted after stirring the sample for $1 \mathrm{~min}$ with $0.1 \mathrm{~mol} \cdot \mathrm{l}^{-1} \mathrm{HCl}$ solution and allowing the reaction to proceed for 4 hours at a soil/solution ratio of 1:5. Then, samples were filtered (Whatman 42 ashless, $2.5 \mu \mathrm{m}$ ) and conserved at $4^{\circ} \mathrm{C}$. The total metal concentrations were determined using flame atomic absorption spectrometry for $\mathrm{Cu}, \mathrm{Fe}$ and $\mathrm{Zn}$ (Schimadzu Atomic Spectrophotometer AA6300 with autosampler ASC6100) and graphite furnace spectrometry (GBC AVANTA $\Sigma$ A5954, auto- 
Table 1. Sampling site locations and descriptions.

\begin{tabular}{cccc}
\hline $\begin{array}{c}\text { UTM } \\
\text { coordinate } \\
(\mathbf{X})\end{array}$ & $\begin{array}{c}\text { UTM } \\
\text { coordinate } \\
(\mathbf{Y})\end{array}$ & $\begin{array}{c}\text { Soil sampling } \\
\text { points }\end{array}$ & Description \\
\hline 371822 & 589263 & Ps 1 & Banana plantation \\
360824 & 589825 & Ps 2 & Rubber plantation \\
364087 & 589460 & Ps 3 & Rubber plantation \\
369825 & 597701 & Ps 4 & Palm plantation \\
367153 & 591401 & Ps 5 & Cleared and burned land \\
372722 & 587491 & Ps 6 & Rubber plantation \\
370106 & 590557 & Ps 7 & Rubber plantation \\
368531 & 592554 & Ps 8 & Rubber plantation \\
367884 & 587491 & Ps 9 & Banana plantation \\
365718 & 587744 & Ps 10 & Bare soil \\
365043 & 588532 & Ps 11 & Bare soil \\
363862 & 587604 & Ps 12 & Banana plantation \\
360853 & 588054 & Ps 13 & Rubber plantation \\
359587 & 590529 & Ps 14 & Banana plantation \\
363440 & 591035 & Ps 15 & Rubber plantation \\
367040 & 588616 & Ps 16 & Casava plantation \\
369684 & 593144 & Ps 17 & Casava plantation \\
372103 & 596604 & Ps 18 & Rubber plantation \\
370781 & 598235 & Ps 19 & Rubber plantation \\
371231 & 591119 & Ps 20 & Banana plantation \\
365943 & 594072 & Ps 21 & Rubber plantation \\
\hline 363496 & 588813 & Ps 22 & Sheep farm \\
\hline
\end{tabular}

sampler PAL 3000) for $\mathrm{Cd}, \mathrm{Cr}$ and $\mathrm{Pb}$.

\subsection{Soil Pollution Index}

The pollution index (PI) is the ratio obtained by dividing the concentration of each metal in the soil by the baseline or background value (concentration in unpolluted soil) [18]:

$$
P I=\frac{C_{\text {heavy metal }}}{C_{\text {background }}}
$$

The data on the geochemical background of the region in general does not exist in Abidjan area. Therefore, in this study the background data $(\mathrm{Cu}=28.1 \mathrm{ppm}, \mathrm{Zn}=$ $843.7 \mathrm{ppm}, \mathrm{Cd}=1.67 \mathrm{ppm}, \mathrm{Cr}=75 \mathrm{ppm}, \mathrm{Pb}=90.3 \mathrm{ppm}$, $\mathrm{Fe}=19024.8 \mathrm{ppm}$ ) was obtained from [19] in an unpolluted area located in the commune of Abobo, eastern part of the study area. For the entire sampling site, the pollu- tion load index $(P L I)$ was determined as the $n$th root of the product of the $n P I[20]$ :

$$
P L I=\left(P I_{1} \times \mathrm{PI}_{2} \times \mathrm{PI}_{3} \times \mathrm{PI}_{4} \times \ldots \ldots \ldots \ldots \ldots \times P I_{n}\right)^{1 / n}
$$

This index provided a simple comparative means for assessing the level of heavy metal pollution and was then classified as no pollution $\mathrm{C} 1(P L I<1)$, moderate pollution $\mathrm{C} 2(1<P L I<2)$, heavy pollution $\mathrm{C} 3(2<P L I<3)$, and extremely heavy pollution $\mathrm{C} 4(3>P L I)$.

\section{Results and Discussion}

\subsection{Soil Characteristics}

The characteristics of the soil samples from the Songon area are presented in Table 2. The soils of the study area are neutral and alkaline $(6.7 \leq \mathrm{pH} \leq 9.20)$. Generally, the results of studies show that tropical soils are acidic $[21,22]$. Therefore the increasing of $\mathrm{pH}$ to neutral and alkaline in this area can be related to the use of fertilizers in agro-industrial plantations in the Songon area. $\mathrm{pH}$ is one of the factors which influence the transport of heavy metal in the soil and according to [23] heavy metal mobility decreases with increasing soil $\mathrm{pH}(\mathrm{pH} \geq 8)$ due to precipitation of hydroxides, carbonates or formation of insoluble organic complexes. Alkaline $\mathrm{pH}$ tends to favor the complexation of metals on the solid matrix. However, the soils of the Songon area are permeable with high hydraulic conductivities $\left(1.9 \times 10^{-5} \mathrm{~m} \cdot \mathrm{s}^{-1} \leq \mathrm{K} \leq 8.2 \times 10^{-4}\right.$ $\left.\mathrm{m} \cdot \mathrm{s}^{-1}\right)$ and high specific yields $(13.33 \% \leq \mathrm{Sy} \leq 33.33 \%)$. These physical characteristics indicate that the soils are sandy clay and clayey sand and confirm those of [24] in the Anguededou zone, including the study area. According to [25], the specific yield has a strong positive correlation with the hydraulic conductivity. Therefore, these parameters intervene directly in the flow velocity of the water and then of dissolved substances. So, even if the phenomenom of complexation predominates, the results indicate that any pollutant associated with water can pass through soil layers in a short transfer time to groundwater. Groundwater transfer in the Akouedo area, located in the same environment of the study area, was estimated between 60 and 120 days by [17]. These results confirm

Table 2. Soil characteristics (pHw, Hydraulic conductivity, specific yield).

\begin{tabular}{cccc}
\hline Sites & $\mathrm{K}\left(\times 10^{-4} \mathrm{~m} \cdot \mathrm{s}^{-1}\right)$ & $\mathrm{Sy}(\%)$ & $\mathrm{pH}$ \\
\hline Min & 0.19 & 13.33 & 6.37 \\
Max & 8.2 & 33.33 & 9.20 \\
Mean & 3.8 & 25.07 & 7.80 \\
SD & 4.0 & 10.05 & 1.42 \\
$\mathrm{CV}(\%)$ & 106.54 & 40.09 & 18.15 \\
\hline
\end{tabular}


those of [14] who showed that $84 \%$ of the study area is vulnerable to pollution. The coefficient of variation of $\mathrm{pH}(\mathrm{CV}=18.15 \%)$ being lower, shows that its spatial distributions is homogeneous with respect to Sy $(\mathrm{CV}=$ $40 \%)$ and $\mathrm{K}(\mathrm{CV}=106.54 \%)$, that have higher coefficients of variation.

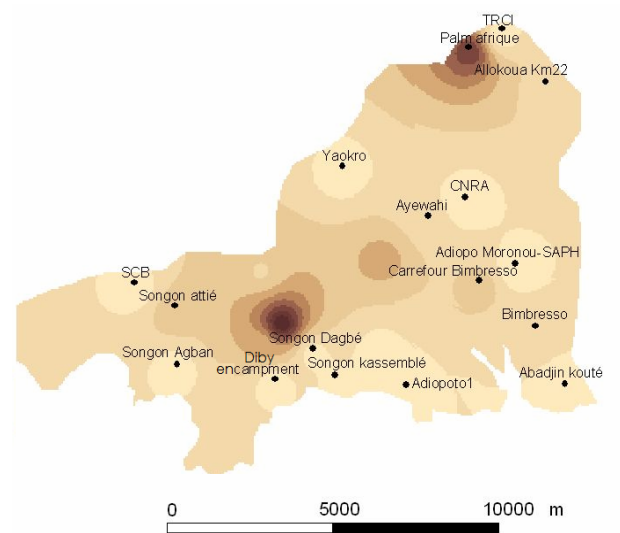

(a)

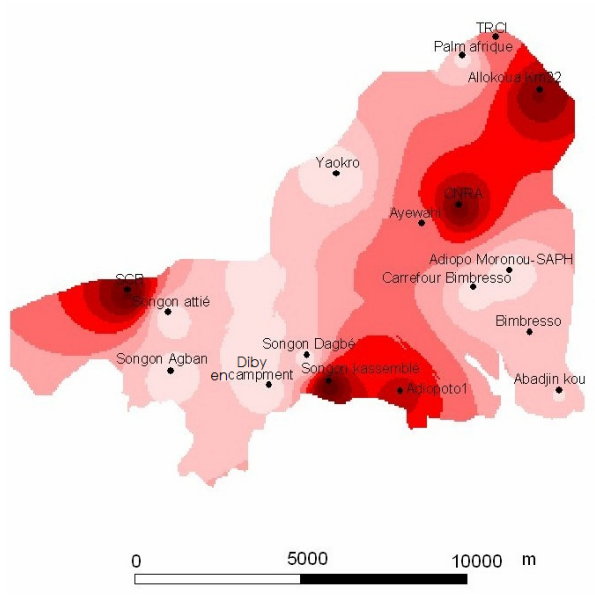

(c)

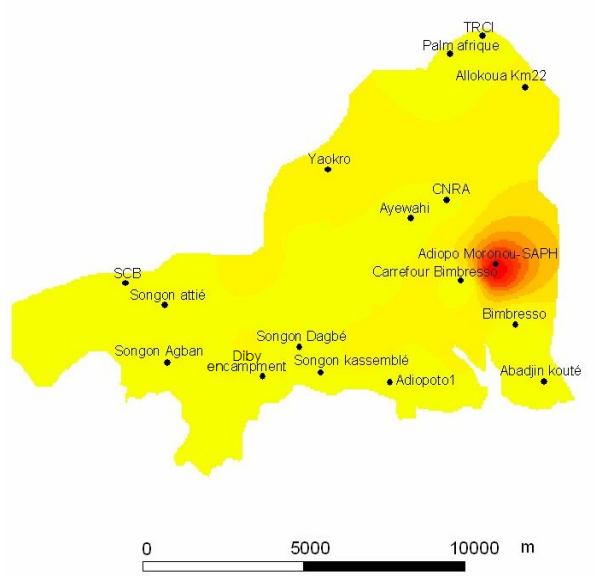

(e)
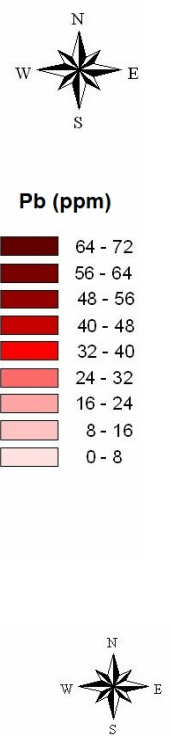

\subsection{Heavy Metal Distribution in Soil}

Figure 2 shows the concentration and distribution of each metal within the study area:

Iron: Fe concentration is higher in the plantation of Palm Afrique and the rubber plantation located between

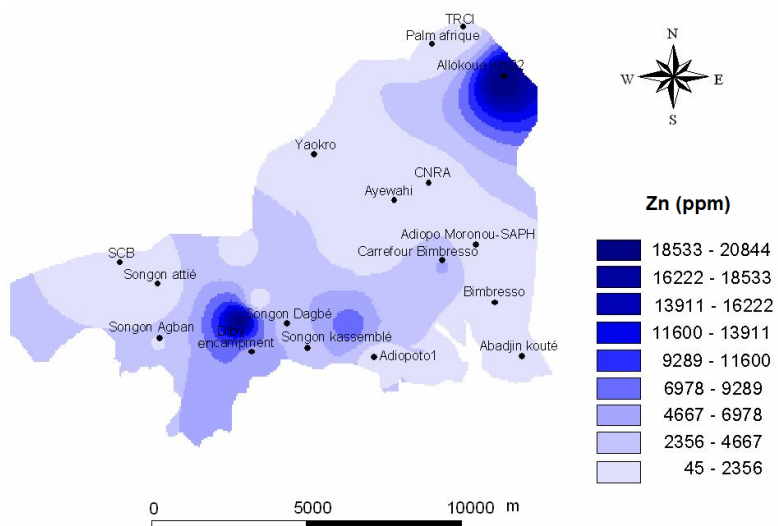

(b)
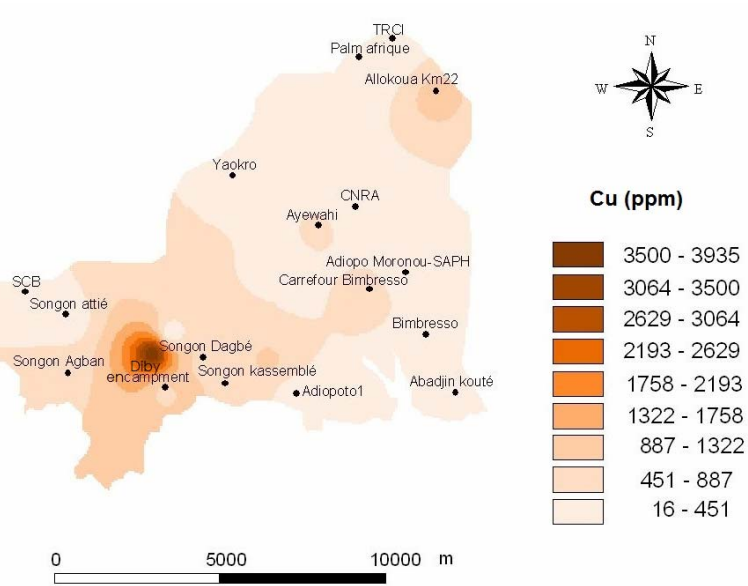

(d)
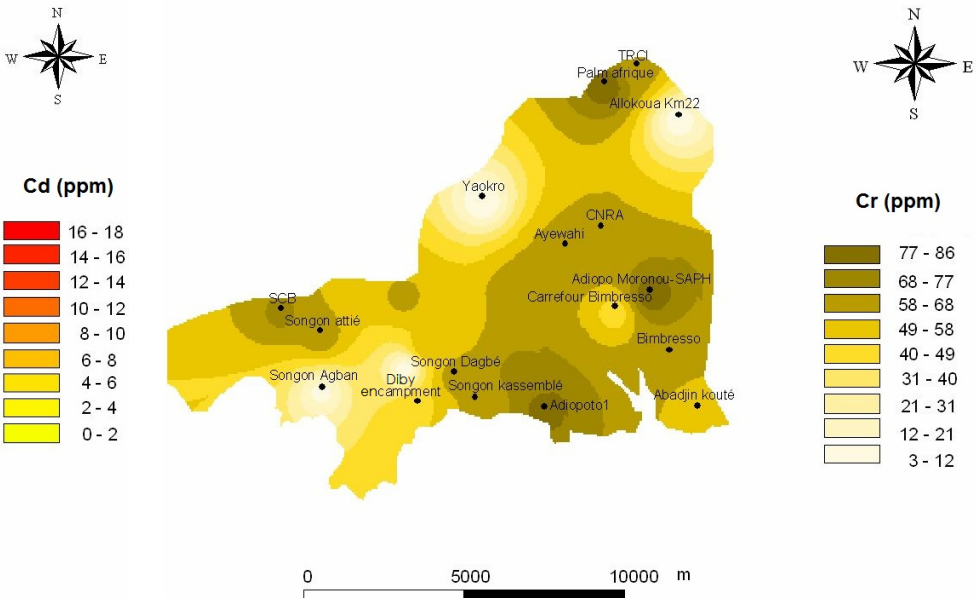

(f)

Figure 2. Heavy metal distribution in the Songon soils. 
the villages of Songon Attié and Songon Agban, and Carrefour Bimbresso, with concentrations ranging between 50.847 and 120.128 ppm (Figure 2(a)). Elsewhere, Fe concentration is low, ranging from 27,753 to 39,300 ppm.

Zinc: Concentrations of $\mathrm{Zn}$ generally vary between 45 and 2084 ppm (Figure 2(b)). Higher Concentrations (ranging between 697 and $2084 \mathrm{ppm}$ ) are found in the rubber, banana and cassava plantations respectively near Allokoua village, Diby escampment and sub-prefecture of Songon. These high observed values were reportedly without the common world range for total $\mathrm{Zn}$ concentrations in soil (10 - $300 \mathrm{ppm})$ [26]. That result could be explained by the intensive use of fertilizers and pesticides in these plantations. According to [26], environmental contamination of $\mathrm{Zn}$ is mainly related to anthropogenic input.

Lead: The $\mathrm{Pb}$ content varies from 0 to $72 \mathrm{ppm}$ (Figure 2(c)). Concentrations of $\mathrm{Pb}$ are very high in the rubber plantation of Allokoua village, the cassava plantation near the National Center for Agricultural Research (CNRA), the banana plantation of the Banana Marketing Company (SCB) and in the villages of Songon Dagbé and Songon Kassemblé bordering the ebrie lagoon. The $\mathrm{Pb}$ values in these localities are higher than the calculated world average of unpolluted soils (44.0 ppm) [27]. Lead is relatively low mobile element because its mobility is restricted by tendency for adsorption to Fe-Mn oxides and insoluble organic matter [28]. Lead is more active by formation of soluble organic complexes, or anionic complexes. But it can enter the environment during fertilization activities, migrate through the soil and contaminate the groundwater when $\mathrm{pH}$ become very low $(\mathrm{pH}<5)$. In the case of area Songon, the high values of hydraulic conductivities and drainage porosities can also favor drainage of lead towards the groundwater.

Copper: $\mathrm{Cu}$ values are very high $(16-3935 \mathrm{ppm})$ at Songon area (Figure 2(d)). The highest values were observed in the banana plantation of the Diby encampment with concentrations ranging from $1322-3935 \mathrm{ppm}$. Moderately high values were also observed in the localities of Allokoua, Carrefour Bimbrinsso, Ayewahi, Songon Agban and Songon Kassemblé. The observed values of the $\mathrm{Cu}$ content exceed the typical world scale of nonpolluted soil (24 ppm) reported by [29] and the value of $28.1 \mathrm{ppm}$ found by [19] in the unpolluted area near the study area. The $\mathrm{pH}$ of the study area ranges between 6.37 and 9.20. At these $\mathrm{pH}$, copper binds preferentially to the oxides of iron, manganese, clays and organic matter [30, 31]. The low mobility of $\mathrm{Cu}$ was observed by [32] at the Akouédo area in the region of Abidjan. Thus, despite having high levels in the soil, $\mathrm{Cu}$ present minor risk of contamination of groundwater.

Cadmium: The $\mathrm{Cd}$ content varies from 0.14 to $18 \mathrm{ppm}$
(Figure 2(e)). However, about $90 \%$ of the Songon area has $\mathrm{Cd}$ content ranges between 0.14 and $6 \mathrm{ppm}$. Only the area around the village of Adiopo Moronou has the highest values (6 - $18 \mathrm{ppm}$ ). Most of the observed values on the Songon area exceed the calculated worldwide mean of non-polluted soil $(0.53 \mathrm{ppm})$ reported after analytical surveys [27] and the value found by [19] in the non-polluted area in the same environment of the study area. $\mathrm{Cd}$ is highly mobile and toxic, which means that the few maxima found are critical values [33]. Concentrations above $1.67 \mathrm{ppm}$ could reflect the influence of the agricultural practices. Indeed, agricultural practices can contribute to increase $\mathrm{Cd}$ levels by releasing of significant quantities of $\mathrm{Cd}$ to the environment [34].

Chromium: The $\mathrm{Cr}$ content ranges from 3 to $86 \mathrm{ppm}$ (Figure 2(f)). Most are observed below $77 \mathrm{ppm}$ values and therefore less than the reported world scale of unpolluted soils (83.0 ppm) [27]. The highest values (77 $86 \mathrm{ppm}$ ) are found in the rubber plantations of localities of Palm Afrique, Adiapo-Moronou, Adiapoto1 and banana plantation of SCB encampment. $\mathrm{Cr}$ is a low mobility element, especially under moderately oxidizing and reducing conditions and near-neutral $\mathrm{pH}$ values. With high $\mathrm{pH}$ values, the predominant form of chromium is $\mathrm{Cr}^{6+}$. Hexavalent chromium is more soluble and thus more bioavailable and potentially toxic [28]. This could lead to a relatively high mobility of chromium in soils and cause contamination of groundwater in the area Songon.

\subsection{Soil Pollution Index}

The integrated pollution indices ( $P L I)$ calculated from Pollution Index, allow a division of the Songon area into three classes (Figure 3$)$. The class $\mathrm{C} 1(P L I<1)$ of not contaminated area by heavy metal is poorly represented and affects only localities of Abadjin Kouté, Songon Dagbé, Songon Attié and the zone located at the east of SCB plantations. The class C3, characterized by highly polluted soils $(2<P L I<3)$ is observed in the sheep farm and in rubber plantations of TRCI, Yaokro and Adiopo

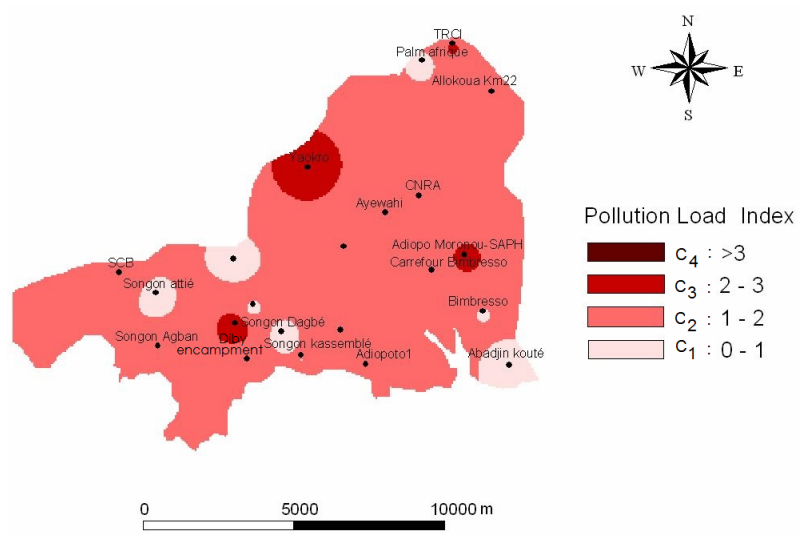

Figure 3. Pollution load index distribution in Songon area. 
Moronou-SAPH. These high pollution indices can be explained by the use of fertilizers and also pesticides in plantations and sheep farms. Areas of high indices of pollution are well integrated into the high vulnerability areas highlighted by [14]. In the class $\mathrm{C}_{2}(1<P L I<2)$, the soils are moderately contaminated by the heavy metals. This class represents almost $70 \%$ of Songon area. The distribution of classes $\mathrm{C}_{2}$ and $\mathrm{C}_{3}$ in Songon area indicate that the groundwater is under a risk of pollution. Therefore, agricultural practices in the Songon area should take into account these heavy metals, in order to avoid groundwater pollution.

\section{Conclusion}

This study permits to observe that Songon soils are neutral and alkaline, with high hydraulic conductivities and specific yields that can favor the pollutant transfer. These soils are of two types in the area: sandy clay and clayey sand. The metals ( $\mathrm{Fe}, \mathrm{Cu}, \mathrm{Zn}, \mathrm{Cd}, \mathrm{Cr}$ and $\mathrm{Pb}$ ) have very high concentrations in soils and the heterogeneity in the spatial distribution of $\mathrm{Cu}, \mathrm{Zn}, \mathrm{Cd}$ and $\mathrm{Pb}$ reflects a probable enrichment of these metals by anthropogenic activties. The integrated pollution indices (PLI) indicate that almost $70 \%$ of Songon soils are moderately contaminated by the investigated heavy metals, with windows presenting high indices of pollution related to the use of fertilizers and pesticides. So, agricultural practices in the Songon area should take into account these heavy metals, in order to avoid risks of groundwater pollution.

\section{Acknowledgements}

The authors would like to thank the International Fund for Science (IFS), the University Agency for Francophonie (AUF) and the Romanian government for the EUGEN IONESCU fellowship and for their support. In addition, the laboratory support for this research by the ARHEOINVEST Interdisciplinary platform (Alexandru Ioan Cuza University) and "Romanian Waters", National Administration Prut-Barlad Water Branch of Iasi is gratefully acknowledged.

\section{REFERENCES}

[1] P. J. M. Sanchez, I. Antiguedad, I. Arrate, C. GarciaLinares and I. Morell, "The Influence of Nitrate Leaching through Unsaturated Soil on Groundwater Pollution in an Agricultural Area of the Basque Country: A Case Study," Sciences of Total Environment, Vol. 317, No. 1-3, 2003, pp. 173-187. http://dx.doi.org/10.1016/S0048-9697(03)00262-6

[2] M. N. Almasri and J. J. Kaluarachchi, "Modeling Nitrate Contamination of Groundwater in Agricultural Watersheds," Journal of Hydrology, Vol. 343, No. 3-4, 2007 , pp. 211-229. http://dx.doi.org/10.1016/j.jhydrol.2007.06.016

[3] W. Tang, B. Shan, H. Zhang and Z. Mao, "Heavy Metal Sources and Associated Risk in Response to Agricultural Intensification in the Estuarine Sediments of Chaohu Lake Valley, East China," Journal of Hazardous Materials, Vol. 176, No. 1-3, 2010, pp. 945-951.

http://dx.doi.org/10.1016/j.jhazmat.2009.11.131

[4] C. Turra, F. E. A. De Nadai, V. A. Stefanuto, M. A. Bacchi, G. A. Sarriés and A. E. L. Reyes, "Arsenic and Chromium in Brazilian Agricultural Supplies," Journal of Toxicology and Environmental Health, Part A, Vol. 73, No. 13-14, 2010, pp. 910-915. http://dx.doi.org/10.1080/15287391003744971

[5] G. D. Laing, J. Rinklebe, B. Vandecasteele, E. Meers and F. M. G. Tack, "Trace metal Behaviour in Estuarine and Riverine Floodplain Soils and Sediments: A Review," Sciences of Total Environment, Vol. 407, No. 13, 2009, pp. 3972-3985.

http://dx.doi.org/10.1016/j.scitotenv.2008.07.025

[6] G. R. Bhagure and S. R. Mirgane, "Heavy Metal Concentrations in Groundwaters and Soils of Thane Region of Maharashtra, India," Environmental Monitoring and Assessment, Vol. 173, No. 1-4, 2011, pp. 643-652. http://dx.doi.org/10.1007/s10661-010-1412-9

[7] M. Romic and D. Romic, "Heavy Metal Distribution in Agricultural Topsoils in Urban Area," Environmental Geology, Vol. 43, No. 7, 2003, pp. 795-805.

[8] F. A. Nicholson, S. R. Smith, B. J. Alloway, C. CarltonSmith and B. J. Chambers, "An Inventory of Heavy Metal Input to Agricultural Soils in England and Wales," Science of the Total Environment, Vol. 311, No. 1-3, 2003, pp. 205-219. http://dx.doi.org/10.1016/S0048-9697(03)00139-6

[9] A. Navas and J. Machin, "Spatial Distribution of Heavy Metals and Arsenic in Soils of Aragón (northeast Spain): Controlling Factors and Environmental Implications," Applied Geochemistry, Vol. 17, No. 8, 2002, pp. 961-973. http://dx.doi.org/10.1016/S0883-2927(02)00006-9

[10] K. Loska, D. Wiechula and I. Korus, "Metal Contamination of Farming Soils Affected by Industry," Environment International, Vol. 30, No. 2, 2004, pp. 159-165. http://dx.doi.org/10.1016/S0160-4120(03)00157-0

[11] C. S. L. Lee, X. Li, W. Shi and S. C.-N. Cheung and I. Thornton, "Metal Contamination in Urban, Suburban, and Country Park Soils of Hong Kong: A Study Based on GIS and Multivariate Statistics," Science of the Total Environment, Vol. 356, No. 1-3, 2006, pp. 45-61. http://dx.doi.org/10.1016/j.scitotenv.2005.03.024

[12] X. Li, S.-L. Lee, S.-C. Wong, W. Shi and I. Thornton, "The Study of Metal Contamination in Urban Soils of Hong Kong Using a GIS-based Approach," Environmental Pollution, Vol. 129, No. 1, 2004, pp. 113-124. http://dx.doi.org/10.1016/j.envpol.2003.09.030

[13] S. Maas, R. Scheifler, M. Benslama, N. Crini, E. Lucot, Z. Brahmia, S. Benyacoub and P. Giraudoux, "Spatial Distribution of Heavy Metal Concentrations in Urban, Suburban and Agricultural Soils in a Mediterranean City of Algeria," Environmental Pollution, Vol. 158, No. 6, 2010, pp. 2294-2301. 
1448 Potential Groundwater Pollution Risks by Heavy Metals from Agricultural Soil in Songon Area (Abidjan, Côte d'Ivoire)

http://dx.doi.org/10.1016/j.envpol.2010.02.001

[14] B. Dibi, K. I. Kouame, A. B. Konan-Waidhet, I. Savane, J. Biemi, V. Nedeff and G. Lazar, "Impact of Agriculture on the Quality of Groundwater Resources in Peri-Urban Zone of Songon (Côte d'Ivoire)," Environmental Engineering and Management Journal, Vol. 11, No. 12, 2012, pp. 2173-2182.

[15] K. I. Kouame, B. Dibi, K. Koffi, I. Savane and I. Sandu, "Statistical Approach of Assessing Horizontal Mobility of Heavy Metals in the Soil of Akouedo Landfill Nearby Ebrie Lagoon (Abidjan-Cote d'Ivoire)," International Journal of Conservation Science, Vol. 1, No. 3, 2010, pp. 149160.

[16] D. G. Marsily, "Hydrogéologie Quantitative, Collection Sciences de la Terre," Masson, Paris, 1981.

[17] K. I. Kouame, "Pollution Physico-Chimique des Eaux Dans la zone de la Décharge d'Akouédo et Analyse du Risque de Contamination de la Nappe d'Abidjan par un Modèle de Simulation des Ecoulements et du Transport des Polluants," Ph.D. Thesis, University of Abobo-Adjamé, Côte d'Ivoire, 2007.

[18] X. Wang, M. He, J. Xie, J. Xi and X. Lu, "Heavy Metal Pollution of the World Largest Antimony Mine-Affected Agricultural Soils in Hunan Province (China)," Journal of Soils and Sediments, Vol. 10, No. 5, 2010, pp. 827-837. http://dx.doi.org/10.1007/s11368-010-0196-4

[19] K. J. Kouakou, "Etude des Métaux Traces (Cd, Cu, Pb, $\mathrm{Zn}, \mathrm{Ni}$ ) Dans les sols et les Produits Maraîchers de Deux Sites d'Agriculture dans la Ville d'Abidjan (Côte d' Ivoire)," Ph.D. Thesis, University of Abobo-Adjamé, Côte d'Ivoire, 2009.

[20] D. L. Tomlinson, J. G. Wilson, C. R. Harris and D. W. Jeffrey, "Problems in the Assessment of Heavy-Metal Levels in Estuaries and the Formation of a Pollution Index," Helgoländer Meeresuntersuchungen, Vol. 33, No. 1-4, 1980, pp. 566-575. http://dx.doi.org/10.1007/BF02414780

[21] J. C. Akan, S. I. Audu, Z. Mohammed and V. O. Ogugbuaja, "Assessment of Heavy Metals, pH, Organic Matter and Organic Carbon in Roadside Soils in Makurdi Metropolis, Benue State, Nigeria," Journal of Environmental Protection, Vol. 4, No. 6, 2013, pp. 618-628. http://dx.doi.org/10.4236/jep.2013.46071

[22] N. Touré, A. Yao-Kouamé, K. A. Alui and T. P. Guety, "Evaluation en Eléments Majeurs et Traces Métalliques d'un Environnement de Production Agricole dans la Vallée du Niéki au Sud-Est de la Côte d'Ivoire," Journal of Applied Biosciences, Vol. 34, 2010, pp. 2134-2144. http://www.ajol.info/index.php/jab/index

[23] S. R. Smith and K. E. Giller, "Effective Rhizombium leguminosarum Biovar Trifolii Present in Five Soils Contaminated with Heavy Metals from Long-Term Applications of Sewage Sludge or Metal Mine Spoil," Soil Biol- ogy and Biochemistry, Vol. 24, No. 8, 1992, pp. 781-788. http://dx.doi.org/10.1016/0038-0717(92)90253-T

[24] E. Roose, M. Cheroux, F.-X. Humbel and A. Perraud, "Les Sols du Bassin Sédimentaire de Côte d'Ivoire," Cahiers ORSTOM, Série Pédologie, Vol. 4, No. 2, 1966, pp. 51-92.

[25] L.-E. Bergeron, "L'eau Souterraine Dans la Région de Duplessis, Côte-Nord, Québec: Un Apercu," Organisme de Bassins Versants, Duplessis, 2001.

[26] X. Wang and Y. Qin, "Spatial Distribution of Metals in Urban Top Soils of Xuzhou (China): Controlling Factors and Environmental Implications," Environmental Geology, Vol. 49, No. 6, 2006, pp. 905-914. http://dx.doi.org/10.1007/s00254-005-0122-Z

[27] F. Zhou, H. Guo and Z. Hao, "Spatial Distribution of Heavy Metals in Hong Kong's Marine Sediments and Their Human Impacts: A GIS Based Chemometric Approach," Marine Pollution Bulletin, Vol. 54, No. 9, 2007, pp. 1372-1384.

http://dx.doi.org/10.1016/j.marpolbul.2007.05.017

[28] A. Kabata-Pendias and H. Pendias, "Trace Element in Soils and Plants," CRC Press, London, 2001.

[29] I. K. Kouamé, D. L. Goné, I. Savané, E. A. Kouassi, K. Koffi, B. T. A. Goula and M. Diallo, "Mobilité Relative des Métaux Lourds Issus de la Décharge d'Akouédo et Risque de Contamination de la Nappe du Continental Terminal (Abidjan-Côte d'Ivoire)," Afrique SCIENCE, Vol. 2, No. 1, 2006, pp. 39-56.

[30] M. L. Bloemen, B. Markert and H. Lieth, "The Distribution of $\mathrm{Cd}, \mathrm{Cu}, \mathrm{Pb}$ and $\mathrm{Zn}$ in Topsoils of Osnabrück in Relation to Land Use," The Science of the Total Environment, Vol. 166, No. 1-3, 1995, pp. 137-148. http://dx.doi.org/10.1016/0048-9697(95)04520-B

[31] A. Pichard, M. Bisson, R. Diderich, N. Houeix, C. Hulot, G. Lacroix, J. P. Lefevre, S. Leveque, H. Magaud, A. Morin, M. Rose and G. Pepin, "Fiche de Donnees Toxicologiques et Environnementales des Substances Chimiques: Chrome et ses Derives Inorganiques," INERIS, Paris, 2004.

[32] D. C. Adriano, "Trace Elements in the Territorial Environment, Trace Element in the Environment," SpringerVerlag, New York, 1986. http://dx.doi.org/10.1007/978-1-4757-1907-9 4

[33] D. E. Baker and J. P. Senft, "Cooper-Heavy Metal in Soils," Blackies Academic and Professional, London, 1995.

[34] G. C. Kisku, S. C. Barman and S. K. Bhrgava, "Contamination of Soils and Plants with Potentially Toxic Elements Irrigated with Mixed Industrial Effluent and Its Impact on the Environment," Water, Air \& Soil Pollution, Vol. 120, No. 1-2, 2000, pp. 121-137. http://dx.doi.org/10.1023/A:1005202304584 